\title{
TWO IMPORTANT KARST BOOKS WRITTEN IN LESS SPOKEN LANGUAGES:
}

\author{
PRINCÍPIOS DE CARSTOLOGIA E GEOMORFOLOGIA CÁRSTICA \\ by Luiz Eduardo Panisset TRAVASSOS
}

and

\author{
PRESVLAČENJE KRŠA. POVIJEST POZNAVANJA DINARSKOG KRŠA \\ NA PRIMJERU POPOVA POLJA \\ by Ivo LUČIĆ
}

\author{
Andrej KRANJC
}

Nowadays we are commonly used that important books, containing new data, new theories, new karst and cave descriptions, etc are published in English. This is why a publication in a less familiar language may be less important from the global point of view but may be much more important; of a key importance even, in the community of its language. Hence we are very glad to highlight the importance of two books, one in the (Brazilian) Portuguese which in fact is not at all less spoken language, and another one in the Croatian language; both authors are former students of the Karstology doctoral programme at the University of Nova Gorica (Slovenia).

The first one is Princípios de carstologia e geomorfologia cárstica by Prof. Luiz Eduardo Panisset Travassos. The author, doctor of karstology, is teaching at the post-graduate programme of Geography (Pontifícia Universidade Católica at Belo Horizonte, Brazil), he was the co-ordinator of Seção de História da Espeleologia da Sociedade Brasileira de Espeleologia, and actually he is the co-ordinator of Comitê de Carste para América do Sul da União Internacional de Geografia, and a member of Karst Research Institute ZRC SAZU at Postojna (Slovenia). He wrote many books on karst and caves, just to mention the translation of Cvijić's "Karst", and many adequate articles. In Principles of Karst Geomorphology it is difficult to expect new theories or new explanations of karst surface, but expectations that such book, in fact a text book on karst geomorphology contains the last results published in recent books and articles are fully realized. Among 560 bibliographical units there are over a quarter of them published in the last 10 years. It is interesting and new related to the type of the book that great number of cited works i.e.130 (23\%) there is on Brazilian karst, which provides special interest, both for readers from Brazil as well as for foreigners. And this proves that Travassos' book is not an "amalgam" of different books and text books but has an important original scheme. As the Brazil is relatively young country it is surprising that modern research of caves started in 1835 already. That year Peter W. Lund (1801-1880), the "Father of Brazilian

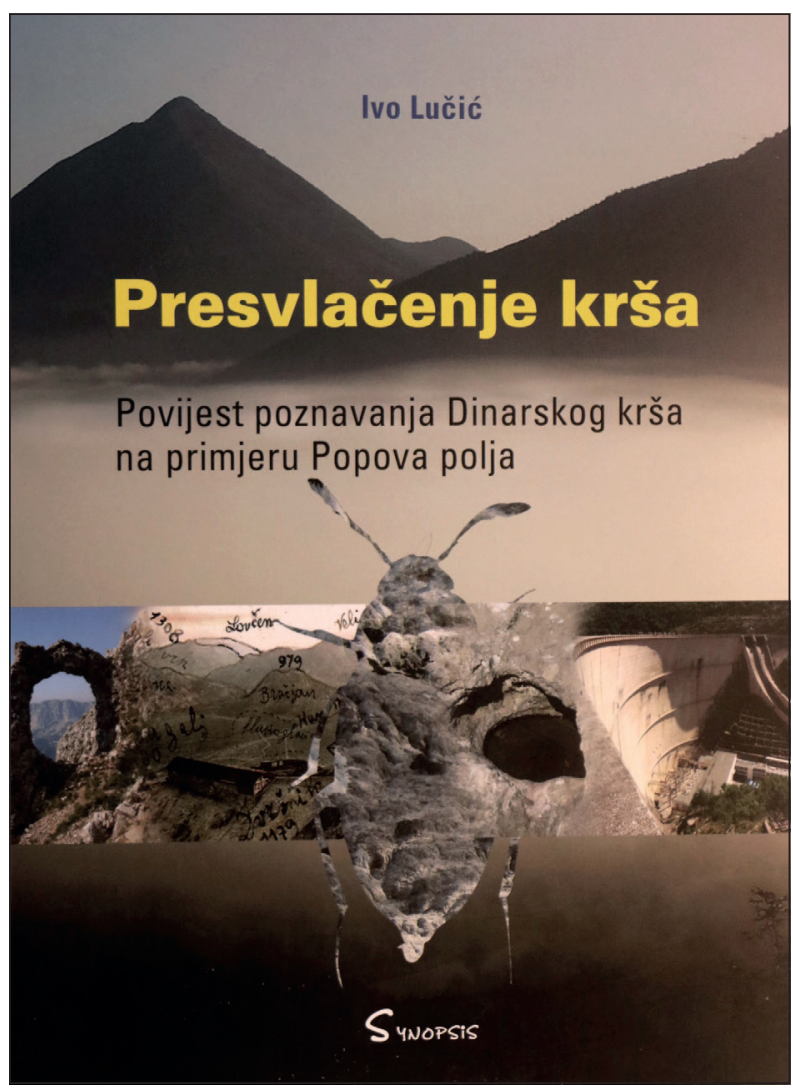

Published by Synopsis (Zagreb-Sarajevo),2019, 680 pp, ISBN 978953-7968-63-2 (Zagreb), the price is 390 Croatian Kuna (52 EUR). 
palaeontology and archaeology" settled at Lagoa Santa (Minas Gerais) and started to dig in numerous caves of the district. And the first work on karst geomorphology was published in 1911. Travassos' book has 242 pages and is divided to traditional chapters, from karst and its definitions, limestone and dolomite to speleothems and speleoclimatology with speleometeorology. Maybe the most important are chapters on karst surface geomorphology (120 pages) and on karst subterraneous geomorphology including speleothems (40 pages). Knowledge and use of traditional terms which had origin from Dinaric Karst (dolina, uvala, polje, ponor) show that the author is well acquainted with this karst, we can say "classical" karst terrains. The last chapters talk on geodiversity, geological heritage, conservation of karst, and life on karst.

The work is richly illustrated with colour photos and nice diagrams, graphs, etc. The last picture has the number 133 but in fact there is much more of them: about 10 of them are full page and not numbered, and many illustrations have more pictures under the same number. In fact there are altogether about 220 illustrations. The same as the bibliography, illustrations also show originality: about a quarter of them are examples from Brazilian karst. And my small remark: among all the illustrations there are 18 showing karst of Slovenia. Among them are Cerkniško and Planinsko Poljes, Postojnska Cave and Škocjan Cave, flagships of our part of Dinaric Karst. In addition to the main topic - karst geomorphology - a reader can get a good impression of karst phenomena in Brazil. I can say it is a good text book for students speaking Portuguese, but it is an interesting karst book for other readers, researchers and scholars included. To conclude I am sure that Slovene students at least would be very happy to have such a text book in Slovene language.

Another book I would like to present is written in a less spoken language, in Croatian, and relates to really narrow topic, one polje only. But in opposition to this "smallness", the book is big and great - large-sized 679 pages. Ivo Lučić is doctor of karstology, he started to work on Popovo Polje for his doctor dissertation and it took him another 10 years to finish this, I can say, monumental book Presvlačenje krša. Povijest poznavanja Dinarskog krša na primjeru Popova polja. The core of the book is Popovo Polje, one of the largest poljes in Dinaric Karst lying in Herzegovina (Bosnia and Herzegovina) in the recharge area east of well-known town Dubrovnik on the Adriatic coast. But the book in fact is not only a detailed description of Popovo Polje and its history; it is much more as is shown by its subtitle: History of Studies on Dinaric Karst, Using the Example of Popovo Polje.

The book contains three main parts: Review of the literature, Discussion, and Synthesis with conclusions.

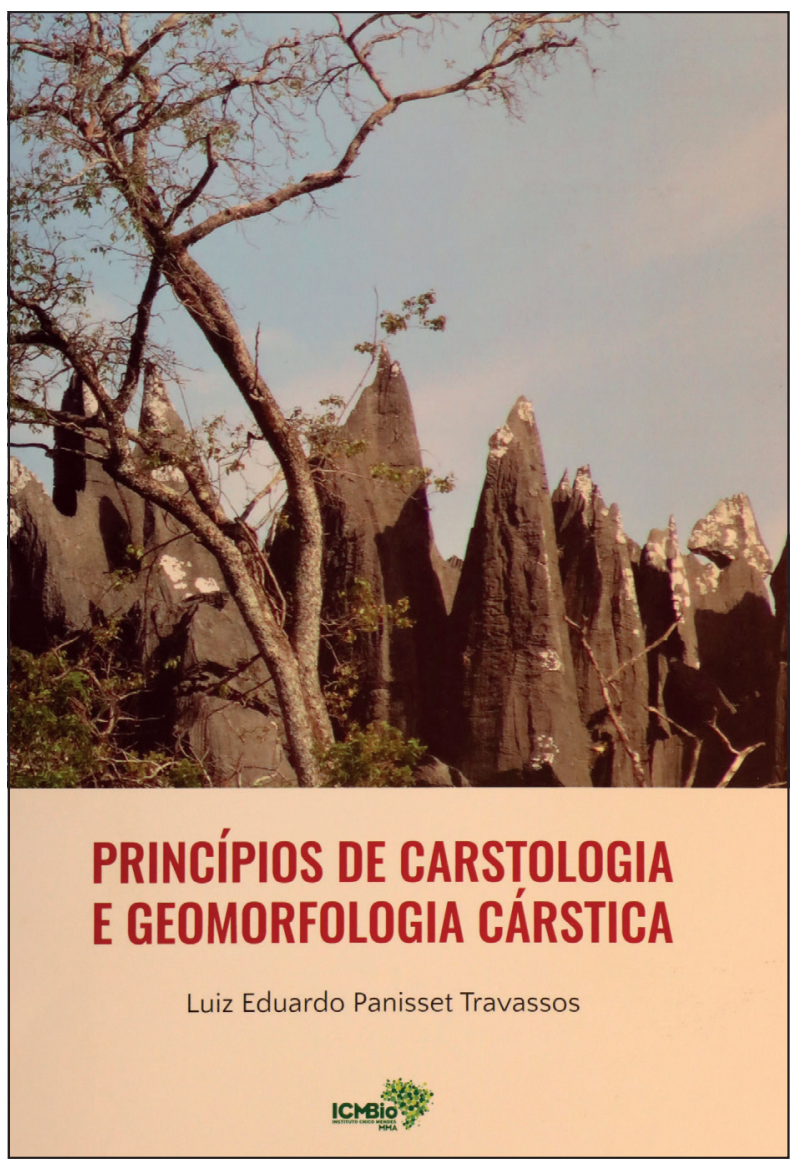

Published by ICMBio, Brasilia, 2019, 242 pp, ISBN 978-65-5024003-5.

Review of literature is not a list of bibliography of the Popovo Polje in a traditional way. In fact it is a detailed study of the main sources concerning Popovo Polje itself and in the context to the Dinaric Karst, discussing its history, the history of the knowledge of its nature in the largest sense of the word, including human geography, economy, and culture in different periods. The first part treats the period until the first half of the $20^{\text {th }}$ Century and the second one from this time on. For a nonconnoisseur it may be surprising that the first notes on Popovo Polje and its karst phenomena are so old. Pliny the Elder mentioned the cave Vjetrenica in his Historia naturalis (77 AD). The first mention of the actual name Vjetrenica appeared in Dubrovnik's documents in 1461 and in the nautical manual of B. Kotruljević (1464). Between years 1570-1574 J. Sorkočević sent a set of letters to famous Italian naturalist $U$. Aldrovandi with complete description of Popovo Polje, emphasized karst and the cave Vjetrenica especially. In 1584 N. Gučetić discussed the origin of the wind from the cave and his work can be considered as the first scientific work on karst underground natural phenomena. Well known Turkish traveller Evlija Celebi from the $17^{\text {th }}$ Century many times 
mentioned Popovo Polje in his diary. In the middle of the $19^{\text {th }}$ century started detailed descriptions of karstological research. Research of Austrian geologists and geographers including J. Cvijić, became the base of the karst science. In continuation there are chapters on traditional life on Popovo Polje under the Ottoman rule and later under Austria, and cultural picture of Popovo Polje to the middle of the $20^{\text {th }}$ Century. The main karstological problem of the second part of the $20^{\text {th }}$ Century was karst water. The chapter with the subtitle "Mercy and misery of industrialization" discussed hydro energetic projects - the region of Popovo Polje and its catchment area are the most exploited and the most radically changed in the whole Dinaric Karst. Further there is discussion on economy (decline of millennium old transhumance, alternation of villages, anthropogenic changes, and tourist development of the Vjetrenica cave). The last chapter of the first part described in details five monographs on Popovo Polje, material culture from Palaeolithic (Crvene stijene station) to the Middle Ages (with emphasis on "Stečak", stone grave monument, particularity of Bosnia and Herzegovina).

The second part of the book consisted of two important chapters on physical karstology - holistic science of karst, and on modernization, that means "de-agrarization" and depopulation. One of subchapters talked about man's impact on nature, in preindustrial times and especially after them, about anthropogenic changes, about the acceptability of the surrounding, and as the last about the cultural landscape. The last subtitle "Land of desert, land of graves" seemed maybe too pessimistic but we must not forget that the author was born on the Popovo Polje so that he does not speak just "scientific truth" but expresses also his feelings. In the third part of the book the author evaluated importance of science regarding Popovo Polje, the use of it and the perception of Polje's landscape. As can be seen from subtitles Co-operation and violence, Cultural landscape, and Perspectives of Popovo Polje, sociologic view is emphasized.
The main text is followed by 20 pages of English Summary, related to the volume of the book, it is not a lot. It ended by bibliography, indexes of names, toponyms, flora and fauna, and professional terms. Bibliography contains 550 units, from old ones (Pliny the Elder, Gučetić, Kotruljević, and Hacquet) to "classical« researchers of Dinaric Karst (Cvijić, Grund, Katzer, and Richter), and to results of actual research on Popovo Polje (Miculinić \& Jalžić 2008 on paleontological research of the cave Vjetrenica) and general theoretical works (Nash 2007 in the review Environmental History). It can be said that this is really the bibliography of Dinaric Karst. Not only wellknown authors like Roglić with 9 units, there are included less known authors but who are not less important for the Dinaric Karst. As an example I would quote Cvijićs disciple S. M. Milojević with 10 units or S. Mikulec with 15 units in this bibliography, dealing mostly with hydrology and water constructions. Index of names, 400 of them, is also surprising regarding the number as well as large diapason of scholars and professionals whose works touched Popovo Polje. Index of flora and fauna has 57 units while the last index of terms consists of 250 units. General terms from different spheres prevail but among them there are 30 exclusively karst terms. At the end it is necessary to mention extremely rich and numerous illustrations. There are pictures of karst landscape and karst phenomena, especially caves, flora and fauna, architecture (pictures of monasteries and water mills have to be mentioned especially), illustrations of economic life (techniques and transport), folklore illustrations, pictures illustrating prehistory, illustrations belonging to the art (characteristic are reliefs on "stećak"), old and modern maps, and cover pictures of important literature on karstology, history, regional literature, and even art literature. Altogether there is over 600 illustrations, including plans, surveys of caves, graphs and tables. I am sure that this book is the greatest work on Popovo Polje and its vicinity, the Dinaric Karst.

Andrej Kranjc 